\title{
頭頸部 悪性黒色腫の検討
}

\author{
林 秀一郎・竹内 万彦・鈴木 慎也
}

Alok Bhandari ・ 間島 雄一

\section{Results of Treatment of Mucosal Malignant Melanoma in the Head and Neck}

\author{
Shuichiro Hayashi, Kazuhiko Takeuchi, Sinya Suzuki, \\ Alok Bhandari and Yuichi Majima \\ (Mie University School of Medicine)
}

\begin{abstract}
Twelve patients with mucosal melanoma of the head and neck were treated in our department between 1984 and 2003. The patient population included five men and seven women, aged 45 to 88 years (mean: 63 years). In six cases, the tumors were localized to the nasal cavity and the paranasal sinuses, in four to the oral cavity, in one to the lacrimal sac, and in one case the primary tumor was unknown.

They were treated with or without multimodal surgery, radiation, chemotherapy, hormonal therapy, and immunotherapy. The 5-year survival rate of all patients was $50 \%$. The survival rates of the patients treated with or without radical surgery showed no difference. However, one patient treated with radical surgery lived for a long term (over 12 years). All patients treated without radical surgery showed local recurrence. The effectiveness of radiation, hormonal therapy and immunotherapy in our patients was not observed.
\end{abstract}

Key words : malignant melanoma, head and neck, therapy

\section{はじめに}

悪性黒色腫は皮膚または粘膜内のメラノサイトから発 生する予後不良の疾患で, そのなかでも頭頸部領域に原 発するものはさらに予後不良とされている，その治療法 には手術療法, 放射線療法, 化学療法, 免疫療法等があ るが，いまだ有効な治療法は確立されていない，今回， われわ机は過去 20 年間に当科で初回加療を行った悪性黒 色腫12例について治療内容の違いとその予後について検 討したので報告する.

\section{対象}

今回対象としたのは, 1984 年から 2003 年までの 20 年 間に当科で初回加療を行った頭頸部粘膜原発の悪性黒色 腫 12 例である. 観察期間は 6 カ月から 12 年であった. 性
別は男性 5 名, 女性 7 名, 年齢分布は $45 \sim 88$ 歳で, 平 均年齢は男性 64 歳, 女性 62 歳であった（図 1 )。

\section{1. 発生部位（表 1)}

原発部位は, 鼻腔 4 例, 副鼻腔 2 例, 口腔 4 例, 涙囊, 原発不明が 1 例ずつであった．細分すると，鼻腔では下 鼻甲介 3 例, 鼻中隔 1 例であった。副鼻腔では上顎洞, 篩骨洞にそれぞれ 1 例認めた。 口腔では, 硬口蓋 3 例, 頬粘膜 1 例であった。

2. 初診時症状（表 1)

初診時の主訴は, 鼻・副鼻腔原発の症例では, 鼻出血 4 例, 鼻閉 3 例で, このうち 2 例は両者を合併していた. また，頸部リンパ節転移を認め，頸部腫瘤を主訴にする 例も 1 例認めた. 口腔原発の症例では色素沈着 3 例, 煩 粘膜の腫脹をきたし摂食困難で来院する例も 1 例あった. 


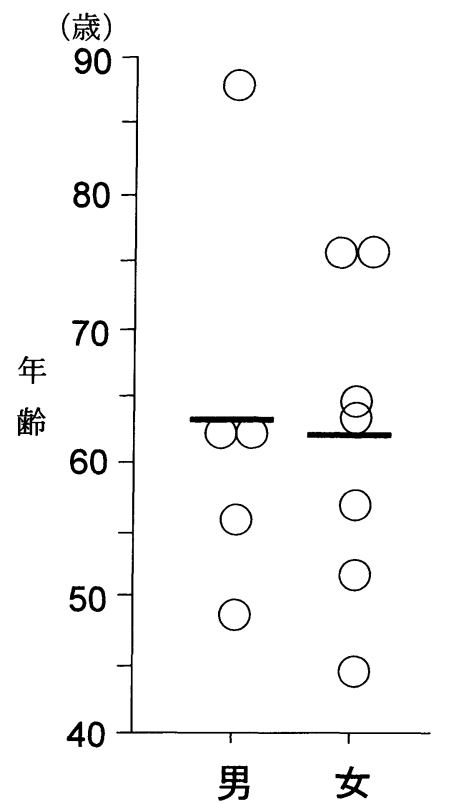

図 1 性別, 年齢

表 1 発生部位, 初診時症状

\begin{tabular}{l|l|l|l}
\hline \hline 氏名 & 年齢 & \multicolumn{1}{|c}{ 原発部位 } & \multicolumn{1}{|c}{ 主訴 } \\
\hline & 45 & 左下鼻甲介 & 鼻閉 \\
\hline & 63 & 左下鼻甲介 & 頸部腫瘤 \\
\hline & 65 & 左下鼻甲介 & 鼻出血 \\
\hline & 76 & 右鼻中隔粘膜 & 鼻閉 鼻出血 \\
\hline & 76 & 右上顎洞 & 鼻出血 \\
\hline & 49 & 右篩骨洞 & 鼻閉 鼻出血 \\
\hline & 57 & 硬口蓋 & 色素沈着 \\
\hline & 64 & 硬口蓋 & 色素沈着 \\
\hline & 56 & 硬口蓋 & 色素沈着 \\
\hline & 88 & 规粘膜 & 煩粘膜腫脹 \\
\hline & 52 & 涙囊 & 眼出血 鼻出血 \\
\hline & 63 & 不明 & 頸部腫瘤 \\
\hline & & &
\end{tabular}

\section{3 . 病期 (表 2 )}

病期分類は頭頸部粘膜原発覀性黒色腫の分類として現 在広く用いられている Ballantyne ${ }^{1)}$ の提案した 3 段階分 類を適応した。 すなわち I 期 : 腫瘍が局所に限局してい るもの，II 期：頸部リンパ節転移を認めるもの，III 期 : 遠隔転移を認めるものである. I 期が 9 例と最も多く, II 期は 3 例, III 期はなかった.

4. 治療内容（表 3 )
表 2 病期 (Ballantyne ${ }^{1)}$ の分類による)

\begin{tabular}{|c|c|c|}
\hline 病期 & 例数 & 部位 \\
\hline I & 9 & 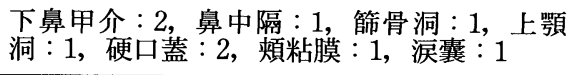 \\
\hline II & 3 & 下鼻甲介 : 1 , 硬口蓋 : 1 原発不明 : 1 \\
\hline III & 0 & \\
\hline
\end{tabular}

表 3 初回治療内容

\begin{tabular}{l|c}
\hline \multicolumn{1}{c|}{ 治療法 } & 例数 \\
\hline 手術+化学療法 & 3 \\
\hline 手術+免疫療法 & 3 \\
\hline 手術＋化学療法＋免疫療法 & 3 \\
\hline 手術＋化学療法＋放射線治療＋免疫療法 & 2 \\
\hline 手術＋化学療法＋放射線治療＋ホルモン療法 & 1
\end{tabular}

表 4 化学療法の内容

\begin{tabular}{|c|c|}
\hline 薬剤内容 & 例数 \\
\hline $\mathrm{DTIC}+\mathrm{ACNU}+\mathrm{VCR}$ (DAV) & 6 \\
\hline $\mathrm{DAV}+\mathrm{PS}$ & 1 \\
\hline $\mathrm{DTIC}+\mathrm{CDDP}+\mathrm{MCNU}$ & 1 \\
\hline $\mathrm{DTIC}+\mathrm{ACNU}$ & 1 \\
\hline 施行ナシ & 3 \\
\hline 計 & 12 \\
\hline
\end{tabular}

治療内容はさまざまであったが，早期に転移をきたし やすいという悪性黒色腫の性質上, ほとんどの症例で化 学療法が加わっていた。 手術療法は全症例に施行されて いたが，術式は局所のみの姑息的手術から根治的拡大手 術までさまざまであった。 また, 放射線療法は 1 回 $4 \mathrm{~Gy}$ で隔日照射行った症例が 2 例あった。

5. 化学療法の内容 (表 4)

今回対象とした 12 例中 9 例に化学療法を行っており, その中心は DTIC (dimethyl triazeno imidazole carboxamide)を主とした多剤併用療法であった。特にDITCによ る多剤併用療法が他施設において普及，報告されるよう になって以来, 当科においても DITC, VCR (vincristine), ACNU (nimutine hydrochloride) を併用した DAV 療法が多 く行われ2), 12 例中 6 例に施行されていた. また, 最近 では CDDP（シスプラチン）を用いた報告もあり ${ }^{344)}$ ，当 
表 5 手術術式

\begin{tabular}{|c|c|c|}
\hline 手術術式 & 例数 & \\
\hline 凍結手術 & 1 & \multirow{6}{*}{6} \\
\hline 凍結手術＋頸部郭清 & 1 & \\
\hline 核出 & 1 & \\
\hline 核出＋凍結手術 & 1 & \\
\hline 局所部分切除 & 1 & \\
\hline 頸部郭清のみ & 1 & \\
\hline 上顎部分切除（lateral rhinotomy） & 2 & \multirow{5}{*}{6} \\
\hline 上顎部分切除+眼窩内容摘出 & 1 & \\
\hline 上顎全摘術 & 1 & \\
\hline 上顎部分切除＋頸部郭清術 & 1 & \\
\hline 前頭蓋底手術＋汎副鼻腔郭清 & 1 & \\
\hline 計 & 12 & \\
\hline
\end{tabular}

科でも 1 例に施行していた.

\section{6. 手術術式（表 5)}

術前より十分な安全域をつけて摘出することを目的と せず，腫䀛の核出や部分切除，あるいは凍結手術を行っ た姑息手術症例は 12 例中 6 例であった. また, 手術によ る根治を目的に行った拡大手術症例は 12 例中 6 例であっ
た.しかし，この拡大手術症例のなかには術中病理にて 断端陽性例が 2 例含まれていた。

7. 過去 20 年間の治療法の選択と予後（表 6)

過去 20 年間の症例を治療時期の古いものから並べた。 1987 年までは拡大手術を行わず，姑息的手術を行ってい た.これらはすべて局所再発をきたし，再発時には主に 手術的に追加切除を行っていた. また, 2000 年頃を境に 放射線療法, インターフェロン $\beta$ にる免疫療法, タモ キシフェンによるホルモン療法等を導入し, 集学的治療 を行ったが予後には改善がみられなかった。 また, 症例 3,5 は初回治療後 6 年以上経過してからの再発であった.

8. 生存率曲線（姑息手術例と拡大手術例）（図 2)

カプランマイヤー法による累積生存率曲線を示す。全 体の 5 年生存率は $50 \%$ だった。拡大手術を行った症例と 姑息手術を行った症例別で検討すると， 5 年生存率は拡 大手術施行例では $67 \%$, 姑息手術例は $26 \%$ で，10 年生

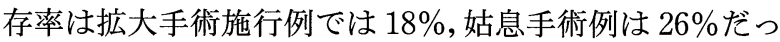
た. また，全体的には 2 群間に有意差を認めなかった。 しかし，拡大手術施行例には，12 年経過観察を行っても 再発を認めない長期生存例があった。

9. 拡大手術例の予後（表 7)

拡大手術を施行し得た個々の症例の経過を示す。拡大

表 6 過去 20 年間の治療法の選択と予後

\begin{tabular}{|c|c|c|c|c|c|c|c|c|c|c|}
\hline & 性別 & 年齢 & 原発部位 & 病期 & 初回治療 & 初回手術 & 局所再発 & $\begin{array}{l}\text { 遠隔 } \\
\text { 転移 }\end{array}$ & $\begin{array}{c}\text { 再発までの } \\
\text { 期間 }\end{array}$ & 予後 \\
\hline 1 & 男 & 63 & 不明 & II & O, OK, B & RND & & & & 不明 \\
\hline 2 & 女 & 57 & 硬口蓋 & I & $\mathrm{O}, \mathrm{C}, \mathrm{OK}$ & 凍結手術 & + & - & 6力月 & 死亡（3 年 5 カ月） \\
\hline 3 & 女 & 64 & 硬口蓋 & I & $\mathrm{O}, \mathrm{C}, \mathrm{OK}$ & 核出＋凍結手術 & + & - & 8 年 8 カ月 & 死亡（11 年） \\
\hline 4 & 男 & 56 & 硬口蓋 & II & $\mathrm{O}, \mathrm{C}, \mathrm{OK}$ & 凍結手術＋RND & 局所担癌 & - & & 死亡 (2 年 11 力月) \\
\hline 5 & 女 & 76 & 鼻中隔 & I & $\mathrm{O}, \mathrm{OK}$ & 局所切除 & + & - & 6 年 8 力月 & 死亡（7 年） \\
\hline
\end{tabular}

1987 年

\begin{tabular}{|c|c|c|c|c|c|c|c|c|c|c|}
\hline 6 & 女 & 52 & 涙囊 & I & $\mathrm{O}, \mathrm{C}$ & 上顎部分切除 + 眼窩内容摘出 & + & - & 2 年 1 力月 & 死亡（7 年） \\
\hline 7 & 女 & 45 & 下鼻甲介 & I & $\mathrm{O}, \mathrm{C}$ & 外側鼻切開 & + & - & 8 年 & 死亡（10 年） \\
\hline 8 & 男 & 63 & 下鼻甲介 & II & $\mathrm{O}, \mathrm{C}$ & 上顎部分切除＋RND & - & - & & 生存（12 年） \\
\hline 9 & 男 & 88 & 頬粘膜 & I & O, I & 核出 & + & - & 2 力月 & 死亡（6力月） \\
\hline
\end{tabular}

2000 年

\begin{tabular}{l|l|l|l|l|l|l|l|l|l|l}
\hline 10 & 男 & 49 & 篩骨洞 & I & O, C, H, R & 前頭蓋底手術+汎副鼻腔郭清 & - & + & 2 力月 & 死亡 (6力月) \\
\hline 11 & 女 & 76 & 上顎洞 & I & O, C, I, R & 上顎全摘 & + & - & 4 力月 & 担癌生存（7カ月） \\
\hline 12 & 女 & 65 & 下鼻甲介 & I & O, C, I, R & 外側鼻切開 & - & + & 5 力月 & 死亡（6力）
\end{tabular}

注 $\mathrm{O}$ : 手術, $\mathrm{C}$ : 化学療法, $\mathrm{R}$ : 放射線療法, $\mathrm{H}$ : ホルモン療法, $\mathrm{OK}: \mathrm{OK}-432, \mathrm{~B}: \mathrm{BCG}, \mathrm{I}: \mathrm{INF} \beta, \mathrm{RND}:$ 頸部郭清 


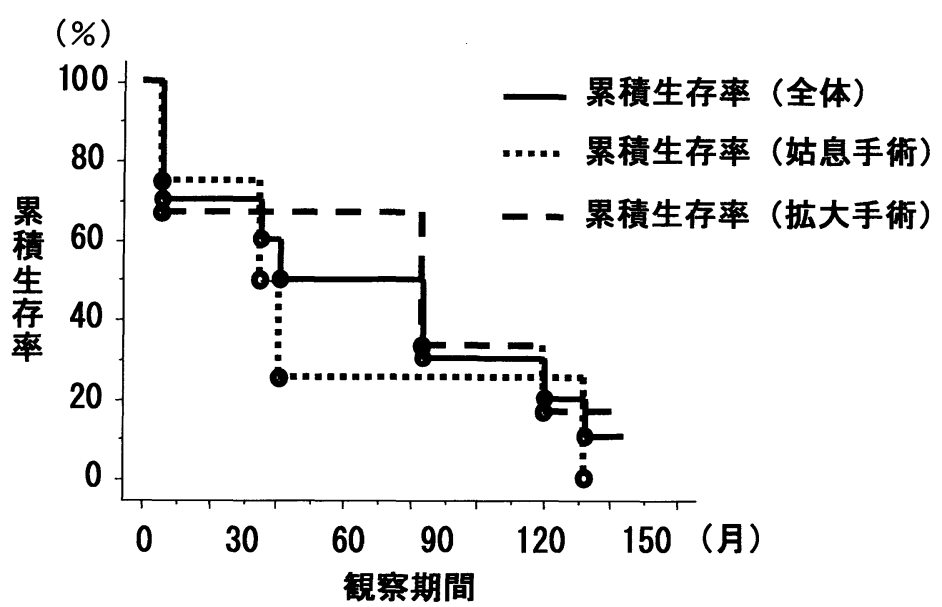

図 2 生存率曲線

表 7 拡大手術例の予後

\begin{tabular}{|c|c|c|c|c|c|c|c|c|c|c|c|}
\hline 症例 & 性別 & 年齢 & 原発部位 & 病期 & 初回手術 & $\begin{array}{l}\text { 腫瘍 } \\
\text { 断端 }\end{array}$ & $\begin{array}{l}\text { 照射 } \\
\text { 線量 }\end{array}$ & 化学療法 & $\begin{array}{c}\text { 免疫療法 } \\
\text { 他 }\end{array}$ & 再発 & 予後 \\
\hline 6 & 女 & 52 & 涙囊 & I & $\begin{array}{l}\text { 上顎部分切除眼窩内 } \\
\text { 容摘出 }\end{array}$ & - & - & $\begin{array}{l}\text { ACNU VCR } \\
\text { DTIC }\end{array}$ & - & 窩内（2 年） & 死亡（7 年） \\
\hline 7 & 女 & 45 & 下鼻甲介 & I & 外側鼻切開 & - & - & ACNU DTIC & $\mathrm{BCG}$ & 咽頭（8 年） & 死亡（10 年） \\
\hline 8 & 男 & 63 & 下鼻甲介 & II & 上顎部分切除 RND & - & - & $\begin{array}{l}\text { ACNU VCR } \\
\text { DTIC }\end{array}$ & - & & 生存（12 年） \\
\hline 10 & 男 & 49 & 篩骨洞 & I & $\begin{array}{l}\text { 前頭蓋底手術汎副鼻 } \\
\text { 腔郭清 }\end{array}$ & + & $36 \mathrm{~Gy}$ & $\begin{array}{l}\text { DTIC CDDP } \\
\text { MCNU }\end{array}$ & $\begin{array}{l}\text { タモキシ } \\
\text { フェン }\end{array}$ & $\begin{array}{l}\text { 頭荎内, 副腎膵 } \\
(2 \mathrm{M})\end{array}$ & 死亡（6力月） \\
\hline 11 & 女 & 76 & 上顎洞 & I & 上顎全摘 & + & $40 \mathrm{~Gy}$ & $\begin{array}{l}\text { ACNU VCR } \\
\text { DTIC }\end{array}$ & IFN $\beta$ & 眼窩内（4M） & $\begin{array}{l}\text { 担癌生存 } \\
\text { (7カ月) }\end{array}$ \\
\hline 12 & 女 & 65 & 下鼻甲介 & I & 外側鼻切開 & - & $36 \mathrm{~Gy}$ & $\begin{array}{l}\text { ACNU VCR } \\
\text { DTIC }\end{array}$ & IFN $\beta$ & 肝, 肺 (5M) & 死亡（6カ月） \\
\hline
\end{tabular}

手術を試みても症例 4,5 のように腫瘍進展例では切除断 端に腫瘍陽性の症例もあった。これらはいずれも術後に 放射線，化学療法等の集学的治療を行った。 しかし，早 期に再発し不幸な転機をたどっていた。一方，長期生存 の症例 8 は下鼻甲介前寄りに限局した腫瘍で，拡大手術 で十分安全域をつけることができた症例であった。

\section{考 察}

頭頸部粘膜原発の悪性黒色腫は近年増加傾向にあると いわれている，鼻・副鼻腔，口腔原発悪性黒色腫の人口 10 万人あたりの発生率は, 1973 年から 1977 年まで 0.031 であったのに対し， 1988 年から 1991 年では 0.056 に増 加したと報告がある ${ }^{5)}$. 当科においては 1984 年から 1993 年までが 8 例で, 1994 年から 2003 年までが 4 例と増加
傾向は認めなかった.

頭頸部領域に発生する悪性黒色腫は粘膜に発生するこ とが多く粘膜原発のものは皮膚原発のものに比べ発症年 齢が高く，予後も不良とされている6).大角7) の報告で は皮膚原発の発症年齢は 49.8 歳であるのに対し,粘膜原 発は 56.5 歳と高年齢とされている. また粘膜原発のもの は 60 歳代に好発するとする文献も多い318)．われわれの 検討も 60 歳代に 4 例と最も多く症例を認めた.

症状として多いものは, 鼻・副鼻腔原発のものでは鼻 出血, 鼻閉であり, 口腔原発のものでは色素沈着あるい は腫瘤であった．谷光ら ${ }^{3)}$ が指摘するように，鼻腔内は 患者自身みることが困難であり，口腔内に発生したもの は初期のらちは無症状のことが多く，いずれも受診を遅 らせる一因になっていると思われる。 また，われわれ耳 
鼻咽喉科医も, 反復する鼻出血, 一側性の鼻閉を訴える 症例で, 特に 60 歳代であれば, ファイバースコープを用 いて鼻腔内を注意深く観察する必要があると思われる.

病期については病期 I 期が最も多く，II 期，III 期は少 ないと報告されている3). われわれの検討でも I 期が 12 例中 9 例と最も多く, II 期は 3 例, III 期はなかった.

治療の選択肢としては, 手術療法, 化学療法, 免疫療 法，インターフェロン療法などが挙げられるが，現在の ところ有効な治療法は確定されておらず，安全域をとっ た広範囲な外科的切除が最も確実とされている．当科の 手術術式の選択は，1987 年以前は凍結手術，核出術等の 姑息手術を行ってきた．これらの予後はすべて局所再発 を認め, 再発時に可能なものは拡大手術を行っていた。 1987 年以降，拡大手術を主とし，安全域をとった手術を 心がけている。しかし，腫瘍が肉眼的に必ずしも黒色病 変を認めないこと, 鼻・副鼻腔が解剖学的に拡大切除が 困難な構造をしていること，さらに周囲への散布巣が存 在することから術前に病変の広がりを把握することは非 常に困難であり，当科でも拡大手術を図ったにもかかわ らず術中病理にて腫瘍断端陽性例を認め，これらの予後 は非常に悪いものであった. 一方, 12 年経過観察を行っ ても再発を認めない長期生存症例は，下鼻甲介に限局し た腫瘍で, 拡大手術（lateral rhinotomy）を施行した症例 であった。

拡大手術施行例と姑息手術施行例の予後を検討してみ ると, 2 群間には有意差は認めなかった. しかし, 姑息 手術例にも再発後拡大手術を施行した症例があったこ と, 拡大手術に踏み切ったにもにもかかわらず腫瘍断端 陽性で結果的に腫瘍が残存した例があったことから, 単 純に拡大手術施行例と姑息手術施行例の予後に差がない とはいい切れないと考える。それよりも，腫瘍が限局し ていても拡大手術に踏み切った症例に予後良好例が存在 したことに注目するべきで，今後もできるがぎり安全域 をつけた拡大手術を第一とする方針である.

しかし，手術で十分な安全域を取れるよう心がけても 頭頸部領域は解剖学的に複雑な構造をしていることから 十分な安全域をとることは難しい. また, どの程度のマー ジンを取れば安全なのか明確な見解もいまだないのが現 状である，そのような背景から，今までに追加治療とし て化学療法, 放射線療法, 免疫療法等が試みられてきた. 当科の化学療法としては, DAV 療法を近年の治療例に 行っている. しかし，化学療法施行中にも再発した例も
認め，十分な治療とはいい切れない状態であった．放射 線療法については，悪性黒色腫は放射線感受性が低いと されていたが，最近 Harwood ら ${ }^{9)}$ は 1 回線量 $4 \mathrm{~Gy}$ 以上 で照射した症例では高い局所制御率を報告し，Gilligan ら ${ }^{10)}$ は 1 回線量 $3 \sim 3.5 \mathrm{~Gy}$ の照射で鼻副鼻腔原発悪性黒 色腫 28 例中 22 例の完全緩解を報告している．われわれ も 1 回線量 $4 \mathrm{~Gy}$ で術後照射を 3 例に施行したが,このい ずれもが早期に再発をきたし，放射線治療の効果は有意 には認められなかった。 さらに，抗エストロゲン剤であ るタモキシフェンを併用して良好な結果を得たとする報 告もある11).われわれも 1 例にタモキシフェンを投与し たが良い結果が得られなかったのが現状であった。

以上のことから，やはり悪性黒色腫は外科的に切除す るのが第一であるが，十分な安全域を取れない症例に対 しては現在の治療では不十分な状態といえる，現在，皮 膚科領域に打いては遺伝子治療の研究も進められてお り，今後期待されるところである.

最後に，初回治療後の経過観察期間であるが，初回治 療後 6 年以上経過して再発をきたした症例もあった. Lund ${ }^{12)}$ やFreedman ら ${ }^{13)}$ の指摘するように, 初回治療から 何年経過しても再発の危険性があることを念頭に置いて 経過観察を行ら必要があると考えられた。

\section{まとめ}

1. 1983 年〜 2003 年までに当科で加療を行った悪性黒 色腫症例 12 例につき，その臨床経過を検討した。

2. 姑息手術例では, 化学療法等を施行しても全例局所 再発をきたした。

3. 拡大手術施行例には, 長期生存例を認めた。

4. 放射線治療, IFN- $\beta$, タモキシフェンの効果は有意 には認められなかった。

\section{参考文献}

1) Ballantyne $\mathrm{AJ}$ : Maligmant melanoma of the skin of the head and neck: an analysis of 405 cases. Am J Surg $4: 425 \sim 431$, 1970.

2) 山田弘之, 鈴村栄久, 山際幹和, 他：頭頸部領域における 覀性黒色腫. 耳喉頭頸 $63: 241 \sim 245,1991$.

3）谷光徳晃, 森 直樹, 平川勝洋, 他 : 頭頸部粘膜原発悪性 黒色腫の臨床統計的検討. 耳鼻臨床 補 $102: 76 \sim 82,1999$.

4）龍頭正浩, 檜垣雄一郎, 冨田吉信 : 当科における頭頸部悪 性黒色腫 16 例の臨床的検討. 日耳鼻 104:859 865, 2001 .

5) Chiu NT and Weinstock MA : Melanoma of oronasal mucosa: 
population-based analysis of occurrence and mortality. Arch Otolaryngol Head Neck Surg 122 : $985 \sim$ 988, 1996.

6) Allen AC and Spitz S : Malignant melanoma; a clinicopathological analysis of the criteria for diagnosis and prognosis. Cancer $6: 1 \sim 45,1953$.

7）大角 毅: 本邦における悪性黒色腫の統計的観察 (第 2 報). 皮膚臨床 $19: 227 \sim 283,1977$.

8) Brandwein MS, Rothstein A, Lawson W, et al. : Sinonasal melanoma: a clinicopathologic of 25 cases and literature meta-analysis. Arch Otolaryngol Head Neck Surg 123:290 296, 1997.

9) Harwood AR and Cummings BJ : Radiotherapy for mucosal melanomas. Int J Radiat Oncol Biol Phys $8: 1121 \sim 1126$, 1982.

10) Gilligan D and Slevin NJ : Radical radiotherapy for 28 cases of mucosal melanoma in the nasalcavity and sinuses. Br J Radiol
$64: 1147 \sim 1150,1991$.

11）瀬尾 達, 小笠原寛, 森 裕司, 他: 悪性黒色腫に対する 化学・ホルモン療法. 耳鼻臨床 $88: 1177 \sim 1182,1995$.

12) Lund $V:$ Malignant melanoma of the nasal cavity and paranasal sinuses. J Laryngol Otol $96: 347 \sim 355,1982$.

13) Freedman HM, DeSanto LW, Devine KD, et al. : Malignant melanoma of the nasal cavity and paranasal sinuses. Arch Otolaryngol $97: 322 \sim 325,1973$.

原稿受付：平成16年 4 月 28 日

原稿採択：平成16年 5 月 26 日

別刷請求先 : 林秀一郎

T514-8507 三重県津市江戸橋2-174

三重大学医学部耳鼻咽喉科学教室 